\title{
The Self-Assembly of Irregular Graphs Whose Edges are DNA Helix Axes
}

Phiset Sa-Ardyen, Natasha Jonoska and Nadrian C. Seeman

\section{SUPPLEMENTARY MATERIALS AND METHODS}

Denaturing Polyacrylamide Gel Electrophoresis: These gels contained 8-12\% acrylamide (19:1 acrylamide:bisacrylamide) and 8.3 M urea and were run on a Hoefer SE 600 gel electrophoresis unit at $31 \mathrm{~V} / \mathrm{cm}$ (constant voltage) at $55^{\circ} \mathrm{C}$. The running buffer contained $89 \mathrm{mM}$ Tris $\cdot \mathrm{HCl}$, pH 8.0, $89 \mathrm{mM}$ Boric acid, 2 mM EDTA (TBE). The denaturing sample buffer contained 90\% formamide, $10 \mathrm{mM} \mathrm{NaOH}, 1 \mathrm{mM}$ EDTA and trace amount of Bromophenol Blue and Xylene Cyanol FF. Fischer-Lerman $100 \%$ denaturing gels ${ }^{14}$ contained $4-6 \%$ acrylamide (37.5:1 acrylamide:bisacrylamide), $7 \mathrm{M}$ urea and $40 \%$ formamide, and were run under the same conditions for denaturing gels as indicated above.

Non-denaturing Gel Characterization of the Graph Subunits: A vertex or edge was formed by mixing a stoichiometric quantity of each component strand in $10 \mu \mathrm{L}$ of a buffer that containing $40 \mathrm{mM}$ Tris- $\mathrm{HCl}, \mathrm{pH}$ 8.0, $20 \mathrm{mM}$ acetic acid, $2 \mathrm{mM}$ EDTA, and $12.5 \mathrm{mM}$ magnesium acetate (TAEMg). Each subunit to be assembled contained no less than $0.12 \mu \mathrm{g}$ of each component strand. The mixtures were annealed by first heating to $90{ }^{\circ} \mathrm{C}$ for 3 minutes and then cooling to (room temperature by the following protocol: 15 minutes at $65{ }^{\circ} \mathrm{C}, 10$ minutes at $50{ }^{\circ} \mathrm{C}, 20$ minutes at $37{ }^{\circ} \mathrm{C}, 20$ minutes at room temperature. The annealed subunits were characterized by 
non-denaturing gel electrophoresis, containing 12\% acrylamide (19:1 acrylamide:bisacrylamide). Tracking dye $(1 \mu \mathrm{L})$ containing TAEMg, $50 \%$ glycerol and a trace amount of Bromophenol Blue and Xylene Cyanol FF was added to the annealed samples. The gels were run on a Hoefer SE-600 gel electrophoresis unit at $16 \mathrm{~V} / \mathrm{cm}$ constant voltage at $30{ }^{\circ} \mathrm{C}$ with TAEMg as a running buffer. After electrophoresis, the gel was stained with Stains-all dye (Aldrich).

Non-Radioactive Phosphorylation: $30 \mathrm{pmol}$ of the individual strands forming a vertex or an edge were dissolved in a solution containing $50 \mathrm{mM}$ Tris $\cdot \mathrm{HCl}, \mathrm{pH} 7.5,10 \mathrm{mM} \mathrm{MgCl}_{2}, 10$ mM DTT, $25 \mu \mathrm{g} / \mathrm{mL}$ BSA, and $1 \mathrm{mM}$ ATP (1x ligase buffer from New England Biolabs (NEB)). The solutions were then heated at $95{ }^{\circ} \mathrm{C}$ for 4 minutes and allowed to cool down by the following protocol: 20 minutes at $65{ }^{\circ} \mathrm{C}, 10$ minutes at $55^{\circ} \mathrm{C}, 20$ minutes at $37{ }^{\circ} \mathrm{C}$. Unless indicated otherwise, all annealing procedures used in this study followed this protocol. After annealing was completed, 6-9 units of polynucleotide kinase (US Biochemical) were added to the solutions. Incubation proceeded at $37{ }^{\circ} \mathrm{C}$ for 1 hour, followed by heat-inactivation of the enzyme by repeating another round of annealing from $65^{\circ} \mathrm{C}$ to $37^{\circ} \mathrm{C}$.

Radioactive Phosphorylation: In certain vertices (V1, V2, and V5) representative strands were chosen to be radioactively labeled. For such vertices the amount of strands used for preannealed non-radioactive phosphorylation was 20 pmol. For the remaining 10 pmol needed to yield appropriate stoichiometry relative to 30 pmol used for other unlabeled subunits, each component strand was phosphorylated separately. The following modification was made with respect to certain strands in V1, V2, and V5 to be radioactively phosphorylated: the reaction buffer now contained 70 $\mathrm{mM}$ Tris $\cdot \mathrm{HCl}, \mathrm{pH}$ 7.6, $10 \mathrm{mM} \mathrm{MgCl} 2,5 \mathrm{mM}$ DTT (1x polynucleotide kinase reaction buffer, NEB) and approximately $1 \mu \mathrm{M} \gamma$-32P-ATP (specific activity $6000 \mathrm{Ci} / \mathrm{mmol}$, NEN Life Science Products); the solutions were then incubated with 4 units of polynucleotide kinase for 1 hour, followed by the addition of non-radioactive ATP to a final concentration of $1 \mathrm{mM}$, and incubation was allowed to proceed for another $7 \mathrm{~min}$. This last step was necessary to maximize the phosphorylation of 5 ' ends. After heat-inactivation at $65^{\circ} \mathrm{C}$ for $30 \mathrm{~min}$, all the $10 \mathrm{pmol}$ of individually phosphorylated 
strands, radioactive and non-radioactive, were mixed together and annealed to assemble the vertices. Finally these vertices, whose component strand(s) were now radioactively labeled, were combined with 20 pmol of the non-radioactively phosphorylated counterpart to make up a total amount of 30 pmol. 